\title{
Effects of silk sericin on the proliferation and apoptosis of colon cancer cells
}

\author{
Waraporn Kaewkorna, Nanteetip Limpeanchob ${ }^{a}$, Waree Tiyaboonchaib, Sutatip Pongcharoenc ${ }^{*}$, \\ Manote Sutheerawattananonda ${ }^{\mathrm{d}}$
}

aDepartments of Pharmacy Practice and bPharmaceutical Technology, Faculty of Pharmaceutical Sciences, 'Department of Medicine, Faculty of Medicine, Naresuan University, Phitsanulok, and dSchool of Food Technology, Institute of agricultural Technology, Suranaree University of Technology, Nakhon Ratchasima, Thailand.

\begin{abstract}
Sericin is a silk protein woven from silkworm cocoons (Bombyx mori). In animal model, sericin has been reported to have anti-tumoral action against colon cancer. The mechanisms underlying the activity of sericin against cancer cells are not fully understood. The present study investigated the effects of sericin on human colorectal cancer SW480 cells compared to normal colonic mucosal FHC cells. Since the size of the sericin protein may be important for its activity, two ranges of molecular weight were tested. Sericin was found to decrease SW480 and FHC cell viability. The small sericin had higher anti-proliferative effects than that of the large sericin in both cell types. Increased apoptosis of SW480 cells is associated with increased caspase-3 activity and decreased Bcl-2 expression. The anti-proliferative effect of sericin was accompanied by cell cycle arrest at the S phase. Thus, sericin reduced SW480 cell viability by inducing cell apoptosis via caspase-3 activation and down-regulation of Bcl-2 expression. The present study provides scientific data that support the protective effect of silk sericin against cancer cells of the colon and suggests that this protein may have significant health benefits and could potentially be developed as a dietary supplement for colon cancer prevention.
\end{abstract}

Key words: Silk sericin, colon cancer, apoptosis, Bcl-2, caspase-3.

\section{INTRODUCTION}

Colon cancer is one of the most common that causes cancer related deaths worldwide. The incidence is high, especially in developed countries, and it is now rising in developing countries like Thailand (Labianca et al., 2004; Khuhaprema and Srivatanakul, 2008). Genetics, environment, lifestyle, and diet are considered important factors that contribute to the development of colon cancer. Epidemiological studies have indicated that diet significantly influences the risk of colon cancer. Western dietary habits, especially high consumption of fat and red meat, increase risk of colon cancer, whereas high consumption of fruits, vegetables, and dietary fibers probably protect against it (van Breda et al., 2008). Because diet is an important factor for identifying risk of colon cancer, it is believed that $90 \%$ of colon cancer cases could be prevented by dietary intervention or by supplementary diets that protect against colon cancer (Johnson, 2004).

Numerous studies in different experimental systems have shown that fruits and vegetables exert beneficial effects through various mechanisms. The protective effects of fruits and vegetables to reduce colon cancer risk might be the result of their high content of anti-oxidant vitamins and fibers (Campos et al., 2005; Levi et al., 2001; Wogan, 1985). Apart from fruits and vegetables, dietary proteins such as soy, whey, and buckwheat proteins have also been found to reduce the development of colon cancer in animals (Belobrajdic et al., 2003; Hakkak et al., 2001; Liu et al., 2001). Interestingly, a nondietary protein called sericin has been reported to suppress colon tumorigenesis in both mice and rats (Zhaorigetu et al., 2001; Zhaorigetu et al., 2007).
Sericin, a silk protein, is one of the main constituents of silk cocoons, comprising $20-30 \%$ of total cocoon weight (Sasaki et al., 2000). Sericin is insoluble in cold water although it is easily dispersed or solubilised in hot water. Sericin is specifically synthesized in the middle gland of the silk worm, Bombyx mori. Sericin was found to suppress lipid peroxidation and tyrosinase inhibitory activity in an in vitro study (Kato et al., 1998). Interestingly, it is resistant to several proteases, which might make sericin beneficial for colon health (Sasaki et al., 2000; Kato and Iwami, 2002). Moreover, because of its proteinous nature, sericin is a biocompatible and biodegradable material. In addition to its anti-oxidant activity (Fan et al., 2009), sericin exhibits chemopreventive effects by suppressing 7,12-dimethylbenze( $a$ )anthracene/12$O$-tetradecanoyl-phorbol-13-acetate(DMBA-TPA)-induced mouse skin tumorigenesis (Zhaorigetu et al., 2003) and colon tumorigenesis in 1,2-dimethylhydrazine (DMH)-induced colon cancer in animal models (Zhaorigetu et al., 2001; Zhaorigetu et al., 2007). The mechanisms of its chemoprevention are associated with its ability to reduce colonic oxidative stress and colonic cell proliferation, and also to suppress aberrant crypt foci in animals (Zhaorigetu et al., 2001; Zhaorigetu et al., 2007).

It should be noted that sericin preparation from silk cocoons is generally heterogeneous, with various sizes of polypeptides. Since sericin is a polymeric protein, different extraction techniques can provide different sizes or molecular weights of polypeptides consequently, exhibiting different effects (Terada et al., 2005). Thus, the size of sericin appears to be important for its activity. For this reason, the present study investigated the effect of two differently sized sericin preparations on the viability of colonic cell lines, including 
cancerous cells SW480 and normal cells FHC. The effect of sericin on the cell cycle and apoptosis of these cells were investigated. Certain apoptotic cellular pathways involving caspase- 3 activity as well as Bcl-2 and Bax protein expression were also investigated.

\section{METHODS}

Preparation of Sericin

Silk sericin was supplied by the Institution of Agricultural Technology, Suranaree University of Technology, Nakorn Ratchasrima, Thailand. The sericin was classified into 2 types according to isolation techniques; large-size sericin (MW 191$339 \mathrm{kDa}$ ) and small-size sericin (MW 61-132 kDa). Briefly, silk sericin was extracted with deionized water from raw silk yarns of the silkworm Bombyx mori under high pressure and high temperature. The specific extraction condition was under a pending Thai patent (application number 080595). The extract was later dried at $130{ }^{\circ} \mathrm{C}$, and then ground and sieved through a $0.75 \mathrm{~mm}$ screen. The resulting sericin powder was sealed in sterile plastic bags and kept at room temperature until used. The sericin was used by reconstituting it in phosphate-buffered saline (PBS) and was sterilized by autoclaving at $121^{\circ} \mathrm{C}$ for 15 minutes.

\section{Cell culture}

The human colorectal cancer cells (SW480: ATCC number CCL-228) and normal human fetal colonic mucosal cells (FHC: ATCC number CRL-1831) were purchased from the American Type Culture Collection (ATCC: Manassas, VA, USA). The SW480 cells were cultured in Dulbecco's modified Eagle's medium with HamF-12 (DMEM/F-12), supplemented with $10 \%$ fetal bovine serum (FBS) and 100 units $/ \mathrm{ml}$ penicillin and $100 \mathrm{mg} / \mathrm{ml}$ streptomycin, all procured from Gibco, NY, USA. FHC cells were cultured in the above medium, supplemented with $25 \mathrm{mM} \mathrm{N}$-2-Hydroxyethylpiperazine- $\mathrm{N}^{\prime}-2$ ethanesulphonic acid (HEPES) (JRH Biosciences, KS, USA), $5 \mathrm{mg} / \mathrm{ml}$ insulin (Sigma, MO, USA), and $100 \mathrm{ng} / \mathrm{ml}$ hydrocortisone (Sigma). Both SW480 and FHC cells were cultured in a humidified atmosphere of $95 \%$ air and $5 \% \mathrm{CO}_{2}$ at $37^{\circ} \mathrm{C}$.

\section{Cell viability assay}

The cells were plated in 96-well plates at a concentration of $1^{\prime} 10^{4}$ cells per well with complete culture medium. After an overnight incubation, the cells were exposed to various concentrations $(25-1,600 \mathrm{mg} / \mathrm{ml})$ of each type of sericin for 24,48 and $72 \mathrm{~h}$. MTT solution $(0.5 \mathrm{mg} / \mathrm{ml})$ was added to the culture medium $2 \mathrm{~h}$ before the end of the treatment period. Formazan crystals were then lysed with DMSO:ethanol (1:1), and the absorbance was read at $595 \mathrm{~nm}$ using a micro-plate reader (Beckman Coulter, NSW, Australia).

\section{Cell apoptosis assay}

Apoptosis was detected with an annexin V-FITC kit (Becton Dickinson, NJ, USA) according to the manufacturer's instructions. Initially, the cells were plated in a $60-\mathrm{mm}$ culture dish at a concentration of $1^{\prime} 10^{6}$ cells per dish with complete culture medium. After an overnight incubation, the cells were treated with sericin at a concentration of $1600 \mathrm{mg} / \mathrm{ml}$ for 72 h. After treatment, the cells were collected, washed with icecold phosphate-buffered saline (PBS) pH 7.4, centrifuged, and resuspended in $1 \mathrm{X}$ binding buffer. Cells were then stained with annexin V-FITC and propidium iodide (PI) solution, incubated for $15 \mathrm{~min}$ in the dark, and analyzed by FACSCalibur using CellQuestPro software (Becton Dickinson).

Caspase-3 activity assay

The cells were plated in $60-\mathrm{mm}$ culture dishes at a concentration of $1^{1} 10^{6}$ cells per dish with DMEM/F-12 with $10 \%$ FBS. After overnight incubation, the culture medium was replaced with a new complete medium and then treated with sericin at a concentration of $1600 \mathrm{mg} / \mathrm{ml}$ for $72 \mathrm{~h}$. Then, the cells were harvested by trypsinization before caspase- 3 activity was detected by using Caspase-3 fluorimetric kit (Sigma). According to the manufacturer's instructions, caspase-3 activity was detected by using acetyl-Asp-Glu-Val-Asp-7amido-4-methylcoumarin (Ac-DEVD-AMC) as a substrate. The fluorescence of 7-amido-4-methylcoumarin (AMC) was measured at Ex $360 \mathrm{~nm}$ and Em $460 \mathrm{~nm}$.

Western blot analysis

The cells were plated in $60-\mathrm{mm}$ culture dishes at a concentration of $1^{\prime} 10^{6}$ cells per dish with DMEM/F-12 with $10 \%$ FBS. After overnight incubation, the culture medium was replaced with new complete medium and then treated with sericin at a concentration of $1600 \mathrm{mg} / \mathrm{ml}$ for $72 \mathrm{~h}$. After treatment, the cells were lysed and the protein concentrations in cell lysate were determined by using a BCA protein assay kit (Thermo scientific, Rockford, USA). Twenty micrograms of each cell lysate sample were loaded and separated on SDSpolyacrylamide gel electrophoresis (SDS-PAGE). The resulting electrophoresis products were transferred onto a PVDF membrane and were then incubated with specific antibodies against Bcl-2 or Bax and then a secondary antibody conjugated with alkaline phosphatase. The protein bands were detected by using nitro blue tetrazolium chloride/5-bromo-4-chloro-3indolyl phosphate (NBT/BCIP) as a substrate.

\section{Cell cycle analysis}

The cells were plated in $60-\mathrm{mm}$ culture dishes at a concentration of $1^{\prime} 10^{6}$ cells per dish with DMEM/F-12 with $1 \%$ FBS. After overnight incubation, the culture medium was replaced with new complete medium and then treated with sericin at a concentration of $1600 \mathrm{mg} / \mathrm{ml}$ for $72 \mathrm{~h}$. After treatment, the cells were harvested by trypsinization, washed with PBS pH 7.4, and fixed in $70 \%$ ethanol at $4{ }^{\circ} \mathrm{C}$ for $1 \mathrm{~h}$. The cells were then treated with $100 \mathrm{mg} / \mathrm{ml}$ of RNase A at $37^{\circ} \mathrm{C}$ for $30 \mathrm{~min}$ and then stained with $20 \mathrm{mg} / \mathrm{ml}$ of PI (Molecular Probes, Invitrogen, NY, USA) for $30 \mathrm{~min}$ at room temperature in the dark. The cell analysis was performed by FACSCalibur using CellQuestPro software (Becton Dickinson).

\section{Statistical analysis}

All data was expressed as mean \pm standard deviation (SD). The statistical analysis was performed by using a one-way analysis 
of variance (ANOVA) and a two-tailed Student's t-test. The $\mathrm{p}$ values $<0.05$ were considered statistically significant.

\section{RESULTS}

\section{Effect of sericin on SW480 and FHC cell viability}

SW480 colon cancer cells and FHC normal colon cells were treated with small or large sericin at various concentrations $(25-1,600 \mathrm{mg} / \mathrm{ml})$ for 24,48 and $72 \mathrm{~h}$. Both sizes of sericin at all tested concentrations did not affect the viability of either type of cell at treatment periods of 24 and $48 \mathrm{~h}$ (data not shown). At $72 \mathrm{~h}$ of sericin treatment, the viability of SW480 and FHC cells gradually decreased with an increasing concentration of sericin (Figure 1). These findings suggest that sericin has considerably low cytotoxicity to both colon cancer cells and normal colon cells. To compare between small and large sericin, the small sericin has a slightly higher anti-proliferative effect than that of

A

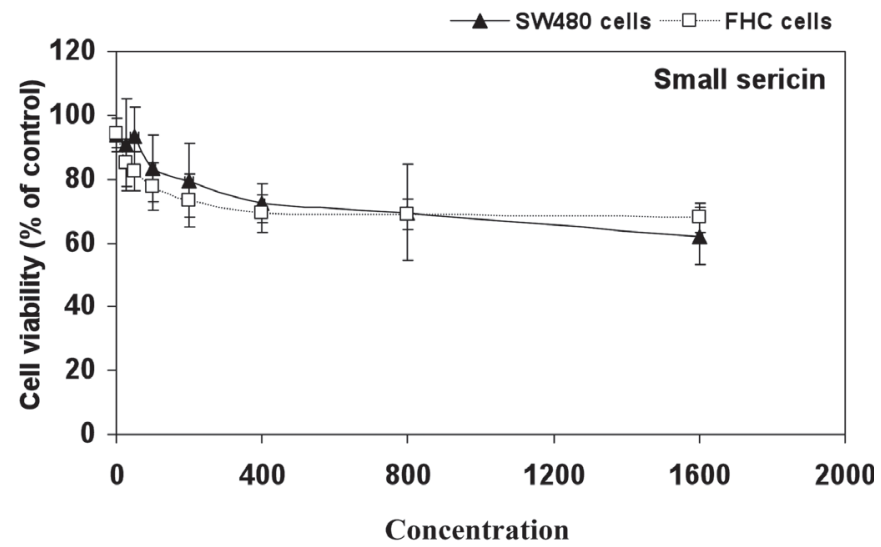

B

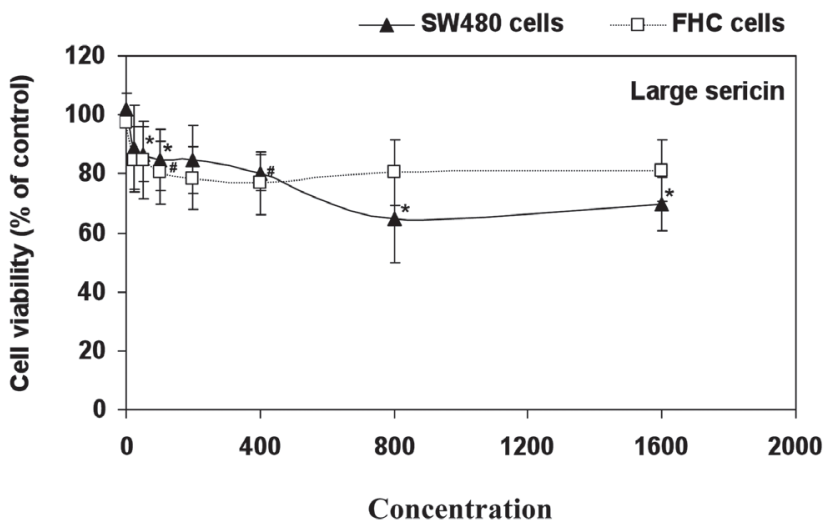

Figure 1: Effect of sericin on SW480 and FHC cell viability. SW480 and FHC cells were incubated with small (A) and large (B) sericin at various concentrations $(25-1,600 \mathrm{mg} / \mathrm{ml})$ for 72 h. The cell viability was determined by MTT assay. Results are expressed as mean \pm SEM and represent the average values from five experiments. ${ }^{*}$ two-tailed Student's $t$-test indicates significant difference compared to control SW480 cells with $p$ values of less than 0.05. \# two-tailed Student's t-test indicates significant difference compared to control FHC cells with $p$ values of less than 0.05 . the large sericin (Table 1). Large sericin seemed to reduce the viability of colonic adenocarcinoma SW480 better than normal FHC cells (Figure 1A), whereas small sericin did not show such differences (Figure 1B). The results suggest that sericin possesses low to moderate effect on the cellular viability for colon cells.

\section{Effect of sericin on SW480 and FHC cell apoptosis}

At $72 \mathrm{~h}$ of treatment, sericin at $1,600 \mathrm{mg} / \mathrm{ml}$ showed a significant reduction of SW480 and FHC cell viability. These cells were then tested as to whether they underwent cell apoptosis or necrosis. The result showed that small but not large sericin significantly increased the percentage of late apoptotic cells in adenocarcinoma SW480 cells (Figure 2A). Neither size of sericin changed the percentage of necrotic cells when compared to the control cells and PBS-treated cells (Figure 2A). In contrast, the colonic normal FHC cells did not undergo cell death either via apoptotic or necrotic processes following sericin treatment (Figure 2B).

Effect of sericin on caspase-3 activity

Caspase- 3 is an executioner caspase, whose activity is increased when cells are about to undergo apoptosis. Therefore, we determined whether or not caspase- 3 activity was directly involved in cell apoptosis induced by sericin. As shown in Figure 3, SW480 cells treated with sericin at 1,600 $\mathrm{mg} / \mathrm{ml}$ for $72 \mathrm{~h}$ exhibited increased caspase- 3 activity. Only the small sericin significantly enhanced caspase-3 activity in SW480 cells. This suggests that sericin, particularly the small-sized, induced adenocarcinoma colonic cells to undergo apoptosis through a caspase-3 dependent pathway.

Effect of sericin on Bcl-2 and Bax expression

The expression of anti-apoptotic protein Bcl-2 and proapoptotic protein Bax were also expected to correlate with the degree of apoptosis of SW480 cells in the previous experiment. The expression of these proteins was examined by using Western blotting. After treating the cells with both sizes of sericin at $1,600 \mathrm{mg} / \mathrm{ml}$ for $72 \mathrm{~h}$, there was a slight reduction of $\mathrm{Bcl}-2$ protein levels, but only the small sericin showed a significant effect (Figure 4). The expression of the Bax protein in sericin-treated cells did not differ from that in the control cells (Figure 4). This suggests that sericin down-regulated anti-apoptotic protein Bcl-2, which may then

TABLE 1

The effect of sericin $(1,600 \mathrm{mg} / \mathrm{ml}, 72 \mathrm{~h})$ on SW480 and FHC cell viability

\begin{tabular}{lccc}
\hline \multirow{2}{*}{ Sericin } & \multicolumn{2}{c}{ Cell viability (\% of control) } & \multirow{2}{*}{ p-value } \\
\cline { 2 - 3 } & SW480 (mean \pm SD) & FHC (mean \pm SD) & \\
\hline Small & $62.16 \pm 8.27$ & $67.90 \pm 4.52$ & 0.17 \\
Large & $69.78 \pm 8.60$ & $81.16 \pm 10.53$ & 0.22 \\
$p$-value & 0.24 & 0.03 & \\
\hline
\end{tabular}

Statistical calculation was performed using Student's t-test. 
enhance adenocarcinoma SW480 cells to undergo an apoptotic process.

\section{Effect of sericin on the cell cycle}

To further investigate whether or not the inhibitory effect of sericin on SW480 cell viability might partially be due to an arrest of cell proliferation, a cell cycle analysis was also conducted by using flow cytometry. After treating the SW480 cells with sericin at $1,600 \mathrm{mg} / \mathrm{ml}$ for $72 \mathrm{~h}$, they were harvested and stained with PI. As shown in Table 2, the colon adenocarcinoma SW480 cells had a higher percentage of cells in the S phase $(19.22 \pm 6.33 \%)$ than FHC normal colonic cells $(7.64 \pm 1.01)$. After treatment with either small or large sericin, the percentage of SW480 cells in the S phase fell below the control level, although the reductions were not statistically significant. Interestingly, both sizes of sericin caused a significant increase in the percentage of the S-phase of FHC cells as compared to the control cells. These results suggest that the cell cycle of adenocarcinoma and normal colonic cell lines are differently regulated by sericin treatment.

\section{DISCUSSION}

Sericin has previously been reported to suppress colon tumorigenesis in animal models (Zhaorigetu et al., 2001; Zhaorigetu et al., 2007). However, there is still a limited number of studies that explain sericin's mechanisms of action

A. SW480 cells

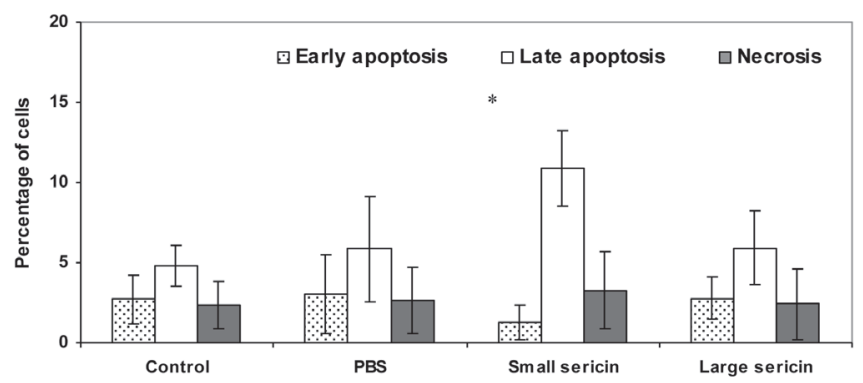

B. FHC cells

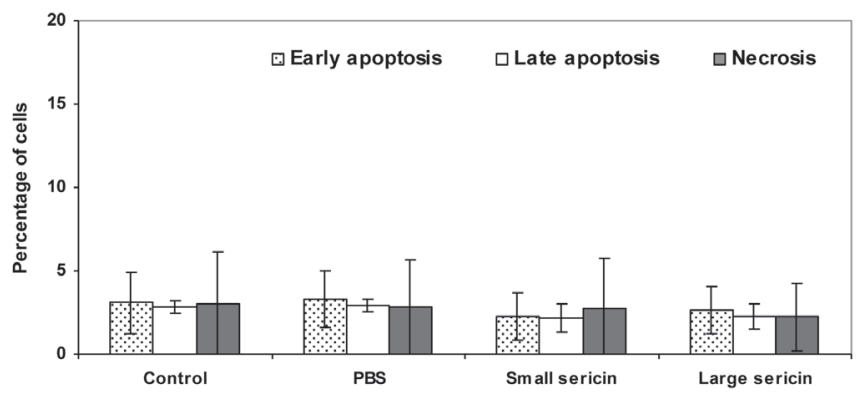

Figure 2: Effect of sericin on SW480 and FHC cell apoptosis. Flow cytometry analysis of cell apoptosis was measured after SW480 (A) and FHC (B) cells were treated with $1,600 \mathrm{mg} / \mathrm{ml}$ of small and large-sizes of sericin for $72 \mathrm{~h}$. Results are expressed as mean \pm SEM and represent the average values from five experiments. * twotailed Student's t-test indicates significant difference compared to control cells with $p$ values of less than 0.05 . for this process. Thus, this present study investigated whether sericin has any effects on colon cancer cells and normal colonic cells. The results showed that sericin exerted a greater inhibitory effect on SW480 cells than on FHC cells. Sericin also exerted a moderate inhibitory effect on the cell viability of SW480 and FHC cells. Small-size sericin (61-132 kDa) reduced the viability of SW480 cells via the induction of cell apoptosis as well as by the reduction of the S-phase cell population. Large-size sericin (191-339 kDa) seems to decrease SW480 cell viability through cell cycle regulation. The sericin-induced apoptsis of SW480 cells was associated with an increase in caspase-3 activity and a down-regulation of Bcl-2 antiapoptotic proteins. Normal FHC colonic cells did not undergo apoptosis, and the cell cycle of these cells changed only slightly after the sericin treatment.

The observed chemopreventative effect may be attributed to several mechanisms, such as suppression of cancer cell proliferation, induction of cell apoptosis, inhibition of angiogenesis, and regulation of the cancer cell cycle. Among these mechanisms, cell apoptosis is the major target for the treatment and prevention of colon cancer (Lifshitz et al., 2001; Sun et al., 2004; Huerta et al., 2006). In the present study, sericin induced late apoptosis in SW480 colon cancer cells but not in FHC normal colonic cells. Early apoptosis is characterized by the changes in the cellular membrane. Phosphatidyl serine, normally located inside the cell membrane, moves to the outer surface, and mitochondrial membrane potential drops. Late apoptosis involves fragmentation of nuclear chromatin. The stages of apoptosis depend on differential apoptotic stimuli, as well as functions of anti-apoptotic and pro-apoptotic proteins (Indran et al., 2011; Kelly et al., 2011; Ascenzi et al., 2011). Malignant transformation of epithelial cells, including those of the colon, also involves various proteins that promote or inhibit apoptosis at different stages (Royer and Lu, 2011). Thus, it is possible that sericin might have an influence on some as yet unidentified proteins associated with the late apoptotic stage in colon cancer cells.

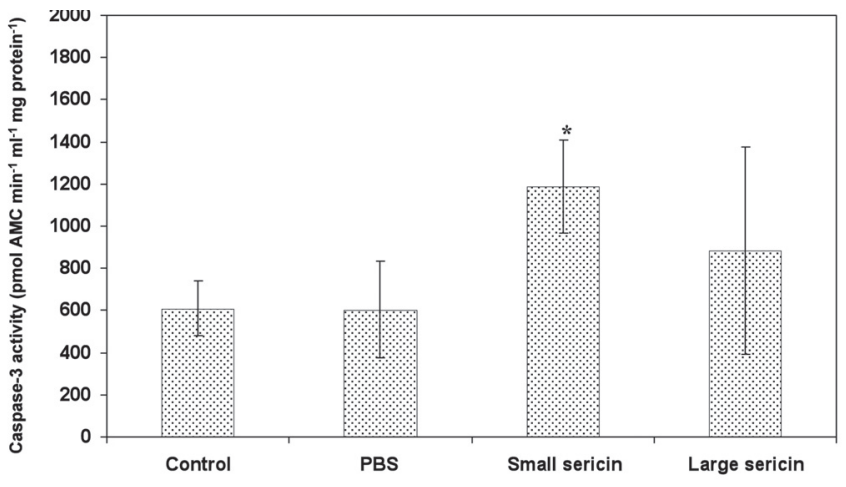

Figure 3: Effect of sericin on caspase-3 activity of SW480 cells. Cells were treated with $1,600 \mathrm{mg} / \mathrm{ml}$ of small and large sizes of sericin for $72 \mathrm{~h}$. The caspase- 3 activity was determined by using Ac-DEVD-AMC, a specific fluorometric substrate for caspase-3. Results are expressed as mean \pm SEM and represent the average values from three experiments. ${ }^{*}$ two-tailed Student's t-test indicates significant difference compared to control cells with $p$ values of less than 0.05 . 
TABLE 2

The effect of sericin $(1,600 \mathrm{mg} / \mathrm{ml}, 72 \mathrm{~h})$ on cell cycle of FHC and SW480 cells

\begin{tabular}{|c|c|c|c|c|c|c|}
\hline \multirow{3}{*}{ Treatment } & \multicolumn{6}{|c|}{ Stage of cell cycle } \\
\hline & \multicolumn{2}{|c|}{ G0/G1 } & \multicolumn{2}{|c|}{ S } & \multicolumn{2}{|c|}{$\mathrm{G} 2 / \mathrm{M}$} \\
\hline & FHC & SW480 & FHC & SW480 & FHC & SW480 \\
\hline Control & $69.79 \pm 4.04$ & $60.46 \pm 6.17$ & $7.64 \pm 1.01$ & $19.22 \pm 6.33$ & $17.08 \pm 3.02$ & $16.49 \pm 8.09$ \\
\hline PBS & $68.56 \pm 5.12$ & $66.20 \pm 2.67$ & $7.90 \pm 2.60$ & $13.54 \pm 3.08$ & $17.06 \pm 3.72$ & $20.11 \pm 5.90$ \\
\hline Small sericin & $69.97 \pm 6.43$ & $70.51 \pm 3.54$ & $9.93 \pm 1.31^{*}$ & $10.46 \pm 3.01$ & $13.11 \pm 2.78$ & $17.98 \pm 2.07$ \\
\hline Large sericin & $67.23 \pm 8.01$ & $67.91 \pm 1.41$ & $10.02 \pm 1.57^{*}$ & $11.00 \pm 2.13$ & $15.26 \pm 2.89$ & $20.21 \pm 0.66$ \\
\hline
\end{tabular}

Results are expressed as mean \pm SD of three experiments. ${ }^{*}$ p value of less than 0.05 compared to control cells.

The mechanisms of apoptosis mainly involve two signaling pathways, namely the intrinsic pathway, involving the activation of the mitochondria and several caspases, and the extrinsic pathway, involving the activation of death receptors (Elmore, 2007). The key element in a mitochondrial pathway is the release of cytochrome $c$ from mitochondria to cytosol to bind to Apaf- 1 and caspase- 9 , and finally to activate caspase- 3 (Shi, 2002). Caspase-3 activity is increased when the cells undergo apoptosis (Stennicke and Salvesen, 1998; Wang et al., 2005). In addition to caspase-3, apoptosis regulatory proteins Bcl-2 and Bax associated with the mitochondrial pathway were also examined. In sericin treated SW480 cells, Bcl-2 was down-regulated, but Bax remained unchanged. These findings suggest that sericin may promote cell apoptosis via the mitochondrial pathway. However, the reduced viability of FHC normal cells induced by sericin was not associated with cell apoptosis. However, the decrease in cell viability after the sericin treatment might have been a result of mechanisms other than apoptosis such as cell cycle regulation.

Cell cycle is a complex process involved in cellular proliferation. A defect in the normal pattern of cell cycle may lead to excessive proliferation and finally to the formation of cancerous cells (Schafer, 1998). Although the present findings showed that sericin had no significant effect on the cell cycle of SW480 cells, the percentage of cells in the G0/G1 phase tended to increase. Interestingly, the cell cycle of FHC cells was arrested at the $S$ phase, indicating that sericin, at least in part, may accelerate cell proliferation in normal colonic cells.

Since sericin is a polymeric protein, different extraction techniques can produce different sizes of sericin. Biological activities of sericin are associated with its molecular weight. Small-size sericin (5-100 kDa) rather than large-size sericin (50-200 kDa) can accelerate the proliferation of hybridoma cells (Terada, 2005). The present results showed that small-size sericin (61-132 kDa), but not large-size sericin (191-339 kDa), significantly reduced cell viability and induced cell apoptosis in SW480 cell. In conclusion, the present study demonstrates that a small sericin of $61-132 \mathrm{kDa}$ has anti-proliferative effects for SW480 human colon carcinoma cells. Sericin could induce cell apoptosis associated with an increase in caspase-3 activity and a decrease in Bcl-2 anti-apoptotic protein expression. Sericin had no cytotoxicity, and indeed it might accelerate cell proliferation of FHC normal colonic cells. Thus, sericin appeared to exert a chemopreventive effect against colon cancer by inducing apoptosis in cancerous cells, whereas this protein had no effect on normal colonic cells. Therefore, sericin may have significant health benefits and it could potentially be developed as a dietary supplement for colon cancer prevention.

A

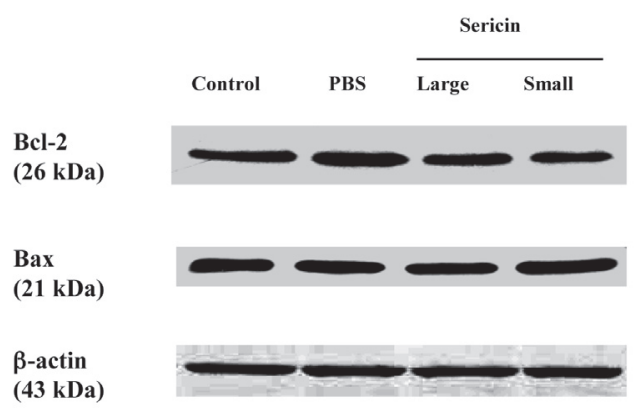

B
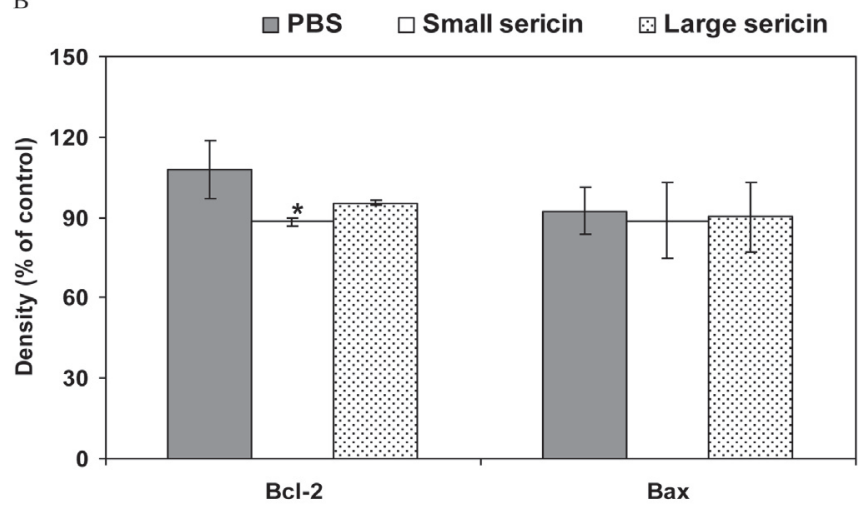

Figure 4: Effect of sericin on the expression of $\mathrm{Bcl}-2$ and $\mathrm{Bax}$ proteins in SW480 cells. Cells were treated with $1,600 \mathrm{mg} / \mathrm{ml}$ of small and large sizes of serica in for $72 \mathrm{~h}$. Twenty micrograms of cell lysates were subjected to SDS-PAGE and immunoblotting was conducted with a specific antibody against $\mathrm{Bcl}-2, \mathrm{Bax}$ or $\beta$-actin (A). The relative abundance of each protein band to its control $\beta$-actin band was estimated by densitometric scanning and calculated to a percentage of the control (B). Results are expressed as mean $\pm S D$ and represent the average values from three experiments. ${ }^{*}$ two-tailed Student's t-test indicates significant difference compared to control cells with $p$ values of less than 0.05 . 


\section{ACKNOWLEDGEMENTS}

This work was supported by the Thailand Research Fund (BRG50800021), the Faculty of Medicine Naresuan University (MD-51-01-015), and Naresuan University (IRDA fiscal year 2009: MD-AR-042/2552). The authors would like to thank Ms. Kwansuda Supalap, Ms.Sanchawan Supalap and Mr. Sang Sriampai for their technical assistance.

\section{REFERENCES}

ASCENZI P, POLTICELLI F, MARINO M, SANTUCCI R, COLETTAM (2011) Cardiolipin drives cytochrom c proapoptotic and anti-aoptotic actions. IUBMB Life 63:160-165.

BELOBRAJDIC DP, MCINTOSH GH, OWENS JA (2003) Whey proteins protect more than red meat against azoxymethane induced ACF in Wistar rats. Cancer Lett 198:43-51.

CAMPOS FG, LOGULLO WAITZBERG AG, KISS DR, WAITZBERG DL, HABR-GAMA A, GAMA-RODRIGUES J (2005) Diet and colorectal cancer: current evidence for etiology and prevention. Nutr Hosp 20:18-25.

ELMORE S (2007). Apoptosis: a review of programmed cell death. Toxicol Pathol 35:495-516.

FAN JB, WU LP, CHEN LS, MAO XY, REN FZ (2009) Antioxidant activities of silk sericin from silkworm Bombyx Mori. J Food Biochem 33:74-88.

HAKKAK R, KOROURIAN S, RONIS MI, JOHNSTON JM, BADGER TM (2001) Soy protein isolate consumption protects against azoxymethaneinduced colon tumors in male rats. Cancer Lett 166:27-32.

HUERTA S, GOULET EJ, LIVINGSTON EH (2006) Colon cancer and apoptosis. Am J Surg 191:517-526.

INDRAN IR, TUFO G, PERVIZ S, BRENNER C (2011) Recent advances in apoptosis, mitochondria and durg resistance in cancer cells. Biochim Biophy Acta 1807:735-745.

JOHNSON IT (2004) New approaches to the role of diet in the prevention of cancers of the alimentary tract. Mutat Res 551:9-28.

KATO N, IWAMI K (2002) Resistant protein: its existence and function beneficial to health. J Nutr Sci Vitaminol 48:1-5.

KATO N, SATO S, YAMANAKA A, YAMADA H, FUWA N, NOMURA M (1998) Silk protein, sericin, inhibits lipid peroxidation and tyrosinase activity. Biosci Biotechnol Biochem 62:145-147.

KELLY RJ, LOPEZ-CHAVEZ A, CITRIN D, JANIK JE, MORRIS JC (2011) Impacting tumor cell-fate by targeting the inhibitor of apoptosis protein surviving. Mol Cancer 10:35.

KHUHAPREMA T, SRIVATANAKUL P (2008) Colon and rectum cancer in Thailand: an overview. Jpn J Clin Oncol 38:243-273.
LABIANCA R, BERETTA G, GATTA G, DE BRAUD F, WILS J (2004) Colon cancer. Crit Rev Oncol Hematol 51:145-170.

LEVI F, PASCHE C, LUCCHINI F, LA VECCHIA C (2001) Dietary fibre and the risk of colorectal cancer. Eur J Cancer 37:2091-2096.

LIFSHITZ S, LAMPRECHT SA, BENHARROCH D, PRINSLOO I, POLAKCHARCON S, SCHWARTZ B (2001) Apoptosis (programmed cell death) in colonic cells: from normal to transformed stage. Cancer Letters 163:229-238

LIU $Z$, ISHIKAWA $W$, HUANG $x$, TOMOTAKE $H$, KAYASHITA J, WATANABE H, KATO N (2001) A Buckwheat Protein Product Suppresses 1,2-Dimethylhydrazine-Induced Colon Carcinogenesis in Rats by Reducing Cell Proliferation. J Nutr 131:1850-1853.

ROYER C, LU X (2011) Epithelial cell polarity: a major gatekeeper against cancer? Cell Death Different 18:1470-1477.

SASAKI M, YAMADA H, KATO N. (2000) Consumption of silk protein, sericin elevates intestinal absorption of zinc, iron, magnesium and calcium in rats. Nutr Res 20:1505-1511.

SCHAFER KA (1998) The cell cycle: a review. Vet Pathol 35:461-478.

SHI Y (2002) Mechanisms of caspase activation and inhibition during apoptosis. Mol Cell 9:459-470.

STENNICKE HR, SALVESEN GS (1998) Properties of the caspases. Biochim Biophys Acta 1387:17-31.

SUN SY, HAIL N, LOTAN R (2004) Apoptosis as a novel target for cancer chemoprevention. J Natl Cancer Inst 96:662-672.

TERADA S, SASAKI M, YANAGIHARA K, YAMADA H (2005) Preparation of silk protein sericin as mitogenic factor for better mammalian cell culture. J Biosci Bioeng 100:667-671.

VAN BREDA SG, DE KOK TM, VAN DELFT JH (2008) Mechanisms of colorectal and lung cancer prevention by vegetables: a genomic approach. J Nutr Biochem 19:139-157.

WANG ZB, LIU YQ, CUI YF (2005) Pathways to caspase activation. Cell Biol Int 29:489-496.

WOGAN GN (1985) Diet and nutrition as risk factors for cancer. Princess Takamatsu Symp 16:3-10.

ZHAORIGETU S, SASAKI M, WATANABE H, KATO N (2001) Supplemental silk protein, sericin, suppress colon tumorigenesis in 1,2-dimethylhydrazine-treated mice by reducing oxidative stress and cell proliferation. Biosci Biotechnol Biochem 65:2181-2186.

ZHAORIGETU S, YANAKA N, SASAKI M, WATANABE H, KATO N (2003) Silk protein, sericin, suppresses DMBA-TPA-induced mouse skin tumorigenesis by reducing oxidative stress, inflammatory responses and endogenous tumor promoter TNF-alpha. Oncol Rep 10:537-543.

ZHAORIGETU S, SASAKI M, KATO N (2007) Consumption of sericin suppress colon oxidative stress and aberrant crypt foci in 1,2-dimethylhydrazine-treated rats by colon undigested sericin. J Nutr Sci Vitaminol 53:297-300. 